\title{
PENGARUH AUDITOR SPESIALISASI INDUSTRI, UKURAN KAP, AUDIT TENURE, KEPEMILIKAN KELUARGA, DAN KUALITAS LABA TERHADAP COST OF EQUITY
}

\author{
Fransiska Bella Sanjaya \\ Universitas Katolik Soegijapranata \\ fransiskabella1@gmail.com
}

\begin{abstract}
This research examines the effect of industry specialization auditor, size of Public Accountant Firm, audit tenure, family ownership, and the quality of profit to cost of equity. Cost of equity as the dependent variable in this research was measured with Earning Price Ratio (EPR). Likewise the independent variable in this research is industry specialization auditor, size of Public Accountant Firm, audit tenure, family ownership, and the quality of profit.This research use secondary data. The data was collected using purposive sampling at company that is registeres at Indonesian Stock Exchange 2011-2015 periode. Total of the sample iin this research is 720 companies. The test equipment in this research using multiple regression test.The result of this research show that industry specialization auditor and the quality of profit has positive effect to cost of equity. Audit tenure has significant effect to cost of equity. Meanwhile size of Public Accountant Firm and family ownership dont have significant effect to cost of equity.
\end{abstract}

Key words: industry specialization, audit tenure, family ownership, earnings quality, cost of equity.

\begin{abstract}
Abstrak
Penelitian ini menguji pengaruh auditor spesialisasi industri, ukuran KAP, audit tenure, kepemilikan keluarga, dan kualitas laba terhadap cost of equity. Variabel dalam penelitian ini yakni cost of equity sebagai variabel dependen diukur dengan Earning Price Ratio (EPR). Serta variabel independen dalam penelitian ini yaitu auditor spesialisasi industri, ukuran KAP, audit tenure, kepemilikan keluarga, dan kualitas laba.Variabelauditor spesialisasi industri dan ukuran KAP menggunakan variabel dummy. Sedangkan variabel audit tenure mengunakan tahun lamanya perikatan. Dan kepemilikan keluarga diukur dengan menggunakan persentase kepemilikan keluarga. Penelitian ini menggunakan data sekunder. Pengambilan sample menggunakan purposive sampling. Sample yang digunakan dalam penelitian ini sebanyak 720 perusahaan. Alat uji penelitian ini menggunakan uji regresi berganda.Jenis data yang digunakan adalah data sekunder yang didapat dari annual report tahun 2011-2015. Data pendukung didapatkan dari fact book dan ICMD (Indonesia Capital Market Directory). Hasil dari penelitian ini menunjukan bahwa auditor spesialisasi industri berpengaruh negatif terhadap cost of equity,Sedangkan variabel ukuran KAPtidak memiliki berpengaruh terhadap cost of equity. Variabel audit tenure berpengaruh terhadap cost of equity. Sedangkan variabel kepemilikan keluarga tidak berpengaruh terhadap cost of equity. Dan kualitas laba berpengaruh negatif terhadap cost of equity.
\end{abstract}

Kata kunci: pesialisasi industri, audit tenure, kepemilikan keluarga, kualitas laba, biaya utang. 


\section{PENDAHULUAN}

Laporan keuangan merupakan gambaran kinerja dan pengungkapan informasi perusahaan. Meningkatnya pengungkapan dalam laporan keuangan bermanfaat bagi perusahaan karena dapat menurunkan cost of equity (biaya modal ekuitas). Hal ini membuat perusahaan berupaya untuk menurunkan cost of equity. Cost of equity (biaya modal ekuitas) adalah tingkat pengembalian (return) yang diharapkan para investor atas investasi dengan tingkat risiko tertentu (Hajiha dan Sobhani, 2012). Menurunnya cost of equity ini karena kualitas laporan keuangan tinggi (Desiliani, 2014).

Terdapat beberapa faktor yang dapat mempengaruhi cost of equity perusahaan diantaranya auditor spesialisasi industri, ukuran KAP, audittenure, kepemilikan keluarga, dan kualitas laba. Hajiha dan Sobhani (2012), Herusetya (2012), Kirana (2013) serta Suparno (2013), menguji pengaruh auditor spesialisasi industri terhadap cost of equity menemukan bahwa auditor spesialisasi industri berpengaruh negatif secara signifikan terhadap cost of equity. Pengauditan yang dilakukan oleh auditor yang memiliki spesialisasi industri dapat meningkatkan kualitas audit sehingga angka yang tersaji dalam laporan keuangan bebas dari salah saji yang material dan dapat diandalkan.

Selain auditor spesialisasi industri, ukuran KAP juga merupakan faktor yang mempengaruhi cost of equity perusahaan. Paramita (2012) menemukan KAP Big 4 tidak memiliki kualitas audit yang berbeda dengan KAP second tier dalam perspektif investor yang diukur dengan cost of equity. Penelitian Khurana \& Raman (2004) menunjukkan bahwa klien dari auditor Big 4 memiliki cost of equity yang jauh lebih rendah dibandingkan dengan klien non-Big 4 auditor di perusahaan-perusahaan AS.

Audit tenure juga merupakan faktor yang diyakini dapat mempengaruhi cost of equity perusahaan. Kirana (2013) menguji pengaruh audit tenure terhadap cost of equity nemukan bahwa audit tenure berpengaruh negatif secara signifikan terhadap cost of equity. Menurut Kirana (2013) bahwa Ada 2 teori tentang audit tenure. Teori yang pertama menyatakan bahwa audit tenure yang lebih panjang akan mengurangi kualitas audit karena dapat menyebabkan kompromi independensi auditor, tetapi teori yang kedua menyatakan bahwa audit tenure yang lebih panjang memungkinkan auditor untuk memperoleh pengetahuan khusus dan keahlian tentang operasi perusahaan, sistem akuntansi dan pengendalian internal agar dapat mendeteksi salah saji material dan dengan demikian mampu memberikan kualitas audit yang tinggi. Jika kualitas audit tinggi maka menekan cost of equity perusahaan.

Selain audit tenure, kepemilikan keluarga juga diyakini merupakan faktor yang dapat mempengaruhi cost of equity perusahaan. Perusahaan dengan kepemilikan keluarga sebagai pemegang saham mayoritas memiliki cost of equity yang lebih tinggi dibandingkan perusahaan lainnya. Hal ini disebabkan karena kontrol yang dimiliki oleh pemegang saham mayoritas dan peluang untuk memperoleh keuntungan pribadi lebih besar sehingga investor menginginkan tingkat pengembalian yang lebih tinggi untuk mengkompensasi risiko tersebut (Rebecca dan Siregar, 2013). Ketika perusahaan dimiliki secara mayoritas oleh keluarga tertentu, risiko informasi menjadi lebih besar dan menyebabkan cost of equity menjadi lebih tinggi (Rebecca dan Siregar, 2013).

Kualitas laba (earning quality) juga merupakan faktor yang diyakini dapat mempengaruhi cost of equity perusahaan. Kualitas laba tidak lepas dari praktik manajemen laba karena adanya konflik keagenan. Laba yang berkualitas berkaitan dengan ketepatan informasi mengenai arus kas perusahaan dan mengurangi resiko dimasa 
depan. Ketepatan informasi inilah akan mengarah ke cost of equity yang rendah. Penelitian Ben-Nasr dan Al-Dakhaeel (2015) menyatakan bahwa kualitas laba yang tinggi dikaitkan dengan cost of equity rendah karena asimetri informasi yang rendah sejalan dengan resiko perusahaan menjadi rendah. Menurut Susanto dan Siregar (2011) bahwa kualitas laba yang diukur dengan kualitas akrual dan earning variability dapat berpengaruh negatif secara signifikan terhadap cost of equity perusahaan.

\section{TINJAUAN LITERATUR DAN PERUMUSAN HIPOTESIS}

\section{Teori Agensi}

Teori keagenan (agency theory) merupakan teori yang menjelaskan hubungan mengenai dua pihak dalam mengelola suatu perusahaan, yaitu principal dan agent. Teori keagenan (agency theory) didalamnya terdapat hubungan manajer (agent) dengan pemilik (principal) sebagai hubungan dua individu untuk lebih memahami informasi ekonomi dan bisnis suatu perusahaan. Pemilik (principal) disebut sebagai evaluator informasi, sedangkan manajer (agent) disebut sebagai pengambil keputusan (Kirana,2013). Manajer sebagai agent memiliki tanggung jawab untuk memberikan informasi perusahaan sebagai sinyal untuk principal. Menurut Rebecca dan Siregar (2013) bahwa pemisahan antara fungsi kepemilikan dan pengelolaan perusahaan menimbulkan adanya kemungkinan terjadinya agency problem yang dapat menyebabkan agency conflict, yaitu konflik yang timbul sebagai akibat keinginan manajemen (agent) untuk melakukan tindakan yang sesuai dengan kepentingannya yang dapat mengorbankan kepentingan pemegang saham (principal). Menurut Butar Butar (2014) masalah keagenan muncul ketika manajer mendahulukan kepentingan pribadi daripada kepentingan pemegang saham.

Agency costs disebabkan karena pemegang saham tidak secara langsung mengawasi kegiatan operasional perusahaan yang berpotensi timbulnya konflik kepentingan, dan pemegang saham maupun investor tidak mengetahui nilai ekonomis perusahaan yang sebenarnya. Maka diperlukannya pengendalian, pemantauan, dan transparansi informasi keuangan perusahaan. Investor yang rasional akan melindungi dirinya dengan meningkatkan cost of equity perusahaan (Ashbaugh et al., 2004 dalam Rebecca dan Siregar, 2013). Menurut Kirana (2013) bahwa dalam mengatasi konflik kepentingan yang terjadi antara agent dan principal dibutuhkan pihak ketiga yaitu auditor eksternal yang bertanggung jawab dalam mengurangi asimetri informasi dan meningkatkan kualitas informasi laporan keuangan. Kualitas audit akan mempengaruhi kualitas informasi sehingga dapat mempengaruhi return yang diharapkan oleh investor.

\section{Teori Pensinyalan (Signaling Theory)}

Berdasarkan teori ini, pengumuman laporan keuangan atau laporan audit merupakan informasi yang penting dan dapat mempengaruhi dalam proses pengambilan keputusan (Brigham dan Houston, 2006 dalam Setyorini et al., 2015).Pengungkapan ini dibagi menjadi dua yaitu pengungkapan wajib dan pengungkapan sukarela. Pengungkapan wajib merupakan pengungkapan yang informasinya telah diatur dan merupakan pengungkapan minimal yang harus diungkapkan. Sedangkan pengungkapan sukarela merupakan pengungkapan informasi perusahaan yang membebaskan manajemen dalam memberikan informasi tambahan sebgai dasar dalam pengambilan keputusan. Semakin banyak dan rinci pengungkapan sukarena mengenai operasi perusahaan maka investor dan pihak eksternal lainnya akan menilai perusahaan itu menyajikan informasi secara transparan.Return yang lebih rendah akan menghasilkan cost of equity yang lebih rendah 
karena investor menilai perusahaan sesuai dengan keadaan yang sebenarnya bagi perusahaan.

\section{Teori Stewardship}

Teori Stewardship dibangun di atas asumsi filosofis mengenai sifat manusia yakni bahwa manusia pada hakekatnya dapat dipercaya, mampu bertindak dengan penuh tanggung jawab, memiliki integritas dan kejujuran terhadap pihak lain. Dari teori ini dapat didasari bahwa para pimpinan eksekutif dan manajemen sebagai steward dalam perusahaan akan mengutamakan kepentingan prinsipal dan tidak akan meninggalkan organisasinya sebab steward berusaha mencapai kepentingan organisasinya. Hal ini membuat steward lebih termotivasi untuk memberikan yang terbaik bagi perusahaan dibandingkan dengan kepentingan pribadi.

Perusahaan yang memiliki proporsi kepemilikan keluarga yang cukup besar memiliki kinerja perusahaan yang lebih baik hal ini disebabkan karena anggota keluarga yang berperan sebagai pimpinan ekstekutif dan manajemen memiliki komitmen yang lebih tinggi kepada perusahaannya dan akan mempertahankan perusahaan agar dapat diwariskan kepada generasi berikutnya. Rebecca dan Siregar (2013) menyatakan bahwa kendali oleh keluarga dapat meningkatkan cost of equity. Hal ini karena keluarga sebagai pemegang saham memiliki suatu kepentingan pribadi dan termotivasi mendapatkan keuntungan bagi dirinya sendiri. Hal ini dapat menyebabkan informasi yang disajikan oleh perusahaan tidak mengambarkan kondisi yang sebenarnya.

\section{Nilai Perusahaan}

Nilai perusahaan merupakan presepsi investor dalam keberhasilan mengelolaan perusahaan yang tercermin dalam harga saham di pasar modal. Harga saham yang tinggi membuat nilai perusahaan juga tinggi, dan meningkatkan kepercayaan pasar tidak hanya terhadap kinerja perusahaan saat ini namun juga pada prospek perusahaan di masa mendatang (Hermuningsih Sri, 2013). Nilai perusahaan di pasar modal merupakan hal penting bagi perusahaan itu sendiri. Ketika investor menilai perusahaan itu baik maka investor tidak akan berpikir dua kali dalam berinvestasi di perusahaan tersebut.

Penilaian atau persepsi dari investor sangatlah penting bagi perusahaan karena dapat mempengaruhi kinerja perusahaan terlebih dalam melakukan aktivitas pendanaan (Dwi, et al. 2014).Investor menilai perusahaan itu baik apabila investor percaya akan laba yang disajikan dalam laporan keuangan berasal dari aktivitas riil perusahaaan bukan dari hasil manajemen laba. Perusahaan dinilai baik apabila resiko perusahaan rendah sehingga cost of equity juga akan rendah.

\section{Struktur Modal}

Struktur modal adalah perbandingan atau proporsi antara pendanaan jangka panjang terhadap pendanaan modal sendiri. Struktur modal adalah proporsi pendanaan permanen jangka panjang dengan menggunakan hutang, ekuitas saham preferen dan saham biasa. Struktur modal merupakan trade-off antara risiko yang ditanggung dan tingkat pengembalian yang diharapkan oleh pemegang saham. Kebijakan struktur modal oleh manajer perusahaan akan berdampak pada nilai perusahaan. Hal ini dikarenakan manajer harus mempertimbangkan antara resiko yang dapat mempengaruhi harga saham di pasar modal. Masalah yang akan timbul dalam kebijakan struktur modal adalah apakah tingkat pengembalian yang diharapkan pemegang saham cukup untuk mengkompensasi 
kenaikan risiko yang harus dihadapi pemegang saham, dan seberapa besar proporsi utang dan ekuitas yang optimal (Indrajaya, et al. 2011).

\section{Cost of Equity}

Cost of equity bagi investor merupakan imbal hasil atau tingkat pengembalian yang diharapkan dari resiko penanaman modalnya ke dalam perusahaan yang berupa kepemilikan saham biasa perusahaan tersebut. Bagi perusahaan cost of equity merupakan biaya yang tejadi karena investor tidak menilai perusahaan dengan semestinya.Penilaian yang rendah dikarenakan investor tidak percaya akan laba yang disajikan oleh perusahaan. Laba yang tinggi tetapi berasal dari aktivitas non riil atau dengan manajemen laba maka cost of equity perusahaan akan tinggi. Karena investor menilai perusahaan tersebut kurang baik dalam menjalankan kegiatan operasionalnya.Cost of equity adalah rate of return yang digunakan perusahaan untuk menarik dana dan menjaga nilai perusahaan di pasar modal. Menurut Utami (2005) bahwa Investor menggunakan untuk mendiskontokan deviden yang diharapkan diterima dimasa depan. Cost of equity yaitu tingkat pendapatan minimum yang disyaratkan pemilik modal.

Perusahaan yang bertumbuh akan lebih diminati oleh investor. Hal ini dikarenakan resiko yang ditanggung oleh investor akan berdampak terhadap laba per lembar saham. Jika laba atau keuntungan per lembar saham meningkat maka nilai saham dipasar juga akan meningkat. Secara langsung akan berakibat menurunnya cost of equity karena investor memiliki penilaian bahwa investasi tersebut akan memberikan tambahan kekayaan bagi pemegang saham atau pemilik. Semakin tingginya nilai pasar ekuitas suatu perusahaan maka cost of equity akan semakin kecil, karena dengan penurunan tingkat estimasi risiko terhadap perusahaan dapat mengakibatkan tingkat pengembalian yang diminta oleh investor juga menjadi lebih menurun atau rendah.Bagi investor perusahaan yang dinilai tinggi dengan resiko yang rendah akan menghasilkan cost of equity yang rendah pula. Semakin besar perusahaan maka investor menilai perusahaan tersebut memiliki risiko yang lebih kecil karena perusahaan besar dianggap lebih mudah memperoleh dana dari luar. Resiko dapat dikurangi dengan adanya kualitas audit yang tinggi, kualitas laba yang bisa diandalkan, dan kepemilikan keluarga yang tidak mendominasi di dalam perusahaan.

Pengukuran cost of equity menurut Utami (2005) dipengaruhi oleh model penilaian perusahaan. Terdapat beberapa model penilaian perusahaan antara lain:

a) Model penilaian pertumbuhan konstan (constant growth valuation model). Dasar pemikirannya adalah nilai saham sama dengan nilai tunai (presentvalue) dari semua deviden yang akan diterima di masa yang akan datang (diasumsikan pada tingkat pertumbuhan konstan) dalam waktu yang tidak terbatas ( Model ini dikenal dengan sebutan Gordon model).

b) Capital Asset Pricing Model (CAPM). Biaya modal saham biasa adalah tingkat return yang diharapkan oleh investor sebagai kompensasi atas risiko yang tidak dapat didiversifikasi yang diukur dengan beta.

c) Model Ohlson. Model Ohlson digunakan untuk mengestimasi nilai perusahaan dengan mendasarkan pada nilai buku ekuitas ditambah dengan nilai tunai dari laba abnormal.

Dalam penelitian ini cost of equity diukur dengan Eearning Price Ratio (EPR). Rasio ini digunakan karena merupakan rasio yang paling populer digunakan dalam mengestimasi tingkat pengembalian dalam pasar ekuitas dan merupakan pengukuran yang secara luas diterapkan Hajiha dan Sobhani (2012) dan Desiliani (2014). EPR lebih dapat menangkap efek harga yang ditimbulkan oleh kualitas audit dengan indikasi 
seberapa banyak investor bersedia membayar untuk setiap rupiah laba yang diaudit (Hajiha dan Sobhani, 2012).

\section{Pengauditan (Auditing)}

Menurut Arens et al., (2008) dalam Putri dan Cahyonowati (2014) bahwa pengauditan merupakan proses pengumpulan serta pengevaluasian bukti-bukti mengenai informasi yang dapat diukur dari suatu entitas ekonomi yang dilakukan seorang yang memiliki kompetensi dan independen untuk dapat menentukan dan melaporkan kesesuaian informasi dengan kriteria-kriteria dan peraturan yang telah ditetapkan. Pengauditan merupakan proses yang dilakukan untuk mengurangi adanya asimetri informasi. Informasi keuangan perusahaan dikatakan berguna apabila memiliki empat karakteristik yakni: dapat dipahami, relevan, dapat diandalkan, dan dapat dibandingkan. Karakteristik relevan dan dapat dihandalkan didapatkan karena adanya kualitas informasi yang memadai. Kualitas informasi yang ada dalam laporan keuangan disebabkan adanya kualitas audit. Sedangkan kualitas audit yang ada di dalam laporan auditan karena adanya auditing yang berkualitas.

Herusetya Antonius (2012) audit yang dilakukan KAP berperan penting dalam memberikan kepastian informasi sehingga informasi dapat dihandalkan. Tanpa audit laporan keuangan pemegang saham akan ragu terhadap keandalan informasi keuangan yang diberikan manajer dan investor akan meminta pengembalian investasi atau cost of equity lebih tinggi atas kemungkinan resiko yang akan diterimanya dimasa yang akan datang.

\section{Auditor}

Undang-undang No.5 tahun 2011 dalam Hidayat Taufik (2012) berisi mengenai Akuntan Publik yang didalamnya mengatur mengenai hak, kewajiban, dan larangan bagi akuntan publik. Pasal 25 ayat 1 UU No.5 tahun 2011 menyatakan bahwa akuntan publik wajib menjaga kompetensi profesinya melalui pelatihan profesi secara berkelanjutan, dan berperilkau jujur, bertanggung jawab dan memiliki integritas yang tinggi. Undangundang tersebut dibuat dengan tujuan melindungi kepentingan pemakai laporan keuangan agar mendapatkan informasi yang kredibel dan berkualitas.Auditor merupakan profesi akuntan publik yang telah lulus S1 dan telah memiliki sertifikat CPA.

\section{Kualitas Audit}

Kualitas audit sangat diperlukan oleh para pengguna laporan keuangan untuk memastikan keandalan informasi yang ada didalamnya. Laporan keuangan auditan merupakan laporan keuangan yang telah diaudit oleh auditor di KAP (Kantor Akuntan Publik) tertentu. Informasi-informasi keuangan yang memiliki kualitas tinggi akan mempermudah investor dalam menilai perusahaan dan membantu dalam mengambil keputusan investasi. Kualitas audit akan lebih menekan asimetri informasi antara agent dan principal. Menurut Butar Butar (2014) auditor eksternal diharapkan mencegah manajer melakukan tindakan-tindakan menyimpang yang merugikan pemilik modal. Lebih jauh dikatakan, auditor yang digunakan harus memiliki independensi dan pengetahuan akuntansi dan audit yang mendalam. 


\section{Auditor Spesialisasi Industri}

GAO (Government Accountability Officer) menyimpulkan bahwa auditor spesialisasi industri ikut bertanggung jawab atas tingginya tingkat konsentrasi auditor di banyak industri (Kirana, 2013). Menurut Fitriany, et al. (2015) bahwa auditor spesialisasi industri dapat meningkatkan kualitas audit dan memiliki kepastian informasi yang lebih tinggi dibandingkan auditor yang tidak memiliki spesialisasi. Maka fee yang diterima auditor ini lebih tinggi dibandingkan auditor yang lain. Auditor spesialisasi industri akan memberikan kualitas audit yang lebih tinggi karena dapat menemukan dan mengekpose masalah khusus di di industri tertentu.

Menurut Kirana (20113) ada 2 pendekatan untuk mengidentifikasi auditor spesialisasi industri, yaitu :

1. Market share dalam industri. Pendekatan ini dihitung berdasarkan presentase jumlah klien yang diaudit dalam suatu industri. Pendekatan ini mengasumsikan bahwa auditor spesialisasi industri adalah pemasok jasa audit terbesar dalam suatu industri begitu pula terbesar kedua dan ketiga.

2. Market share dalam KAP. Pendekatan ini sering disebut portofolioshare, yang meggambarkan distribusi pendapatan KAP berdasarkan industri. Pendekatan yang pengukuran auditor spesialisasi industri dengan mengukur portofolio berdasarkan perkiraan proporsi pendapatan auditor spesialisasi industri dari suatu industri dibagi total pendapatan audit dari semua industri.

Andreas (2012) auditor dikatakan spesialisasi industri jika auditor memiliki banyak klien dalam industri yang sama. Auditor spesialis indutri diukur dengan cara yang digunakan oleh Craswell et al. (1995) dalam Andreas (2012). Pertama, sampel industri yang digunakan adalah indutri yang minimal memiliki 30 perusahaan. Kedua, auditor dikatakan spesialis jika auditor tersebut mengaudit $20 \%$ dari total perusahaan yang ada dalam industri tersebut.

\section{Ukuran KAP}

Hardiningsih (2010) ukuran KAP mempengaruhi kualitas audit. KAP yang besar memiliki klien yang lebih banyak karena KAP besar akan menjaga reputasinya agar tidak mengalami kerugian. KAP yang besar akan memberikan kualitas audit yang lebih tinggi untuk menjaga reputasinya. Menurut Undang-undang Akuntan Publik (2011) bahwa seorang akuntan publik harus memiliki ijin dari menteri keuangan agar dapat memberikan jasa akuntan publik. Akuntan publik merupakan lulusan S1 akuntansi dan memiliki sertifikat CPA (Certified Public Accountant). KAP memberikan jasa assurance yang berkaitan dengan konsultasi, perpajakan, akuntansi, dan manajemen. KAP dibagi dalam dua jenis yaitu : KAP big 4 dan non-big 4 sesuai dengan penghasilan global yang diperoleh setiap tahunnya.Desiliani (2014) menemukan bahwa di Indonesia terdapat Big4 yaitu empat kantor akuntan publik yang dianggap memiliki reputasi paling baik. Beberapa alasan perusahaan menggunakan jasa kantor akuntan publik Big4, antara lain : para pemegang saham menginginkan Big4, perusahaan ingin mendapatkan kepercayaan dari para investor atau dukungan dari pasar modal, Big4 mempunyai sumber daya keuangan yang kuat untuk mempertahankan pekerjaanya, perusahaan publik memang dituntut untuk menggunakan The Big4 .

Desiliani (2014) KAP Big 4 dan afiliasinya di Indonesia adalah sebagai berikut.

a. PWC (Price Waterhouse Coopers). Di Indonesia, PWC berafiliasi dengan KAP Tanudiredja, Wibisana \& Rekan. 
b. Deloitte (Deloitte Tohce Tomatsu Limited), merupakan salah satu anggota dari big 4. Di Indonesia Deloitte berafiliasi dengan KAP Osman Bing Satrio.

c. Ernst \& Young (EY), merupakan salah satu anggota dari big-4, dan berada di posisi ketiga diantara big 4. Di Indonesia, Ernst \& Young Berafiliasi dengan KAP Purwantono, Suherman \& Surja.

d. KPMG, merupakan salah satu anggota dari Big4, dan berada di posisi Keempat diantara Big 4. Di Indonesia, KPMG berafiliasi dengan KAP Sidharta dan Widjaja.

\section{Audit Tenure}

Audit tenure adalah masa perikatan (keterlibatan) antara Kantor Akuntan Publik (KAP) dan klien terkait jasa audit yang disepakati atau dapat juga diartikan sebagai lama hubungan kerja antara auditor dengan kliennya. Audit tenure biasanya selalu berkaitan dengan independensi, karena independensi auditor akan menentukan kualitas audit (Kirana, 2013). Fitriany, et al. (2015) Audit tenure jangka panjang akan membuat kedekatan dan loyalitas antara auditor dan klien karena auditor akan merasa nyaman dengan klien tersebut.

Semakin lama audit tenure maka kualitas audit akan semakin menurun (Hardiningsih, 2010). Setyorini, et.al (2015) untuk melindungi kualitas audit maka Pemerintah telah mengatur tentang jangka waktu perikatan audit (audit tenure) dalam PMK Nomor: 17/PMK.01/2008. Peraturan ini menjelaskan bahwa pemberian jasa audit umum atas laporan keuangan dari suatu entitas dilakukan oleh KAP paling lama untuk 6 tahun buku berturut-turut dan oleh seorang Akuntan Publik paling lama untuk 3 tahun buku berturutturut. Akuntan Publik dapat menerima kembali penugasan audit untuk klien tersebut setelah 1 tahun buku tidak memberikan jasa audit umum atas laporan keuangan klien tersebut.

\section{Kepemilikan Keluarga}

Kepemilikan keluarga merupakan kepemilikan perusahaan yang dimiliki oleh sekelompok orang yang masih memiliki hubungan darah. Jika perusahaan didominasi oleh kepemilikan keluarga maka dapat memicu munculnya agency problem antara pemegang saham mayoritas dan pemegang saham minoritas (Villalonga dan Amit, 2005 dalam Rebecca dan Siregar, 2013). Perusahaan yang sebagian besar sahamnya dimiliki oleh keluarga memiliki kelebihan yaitu sudut pandang jangka panjang terhadap operasi bisnisnya sehingga return yang dihasilkan lebih baik bagi perusahaan (Ibrahim dan Samad, 2010 dalam Kusumawati dan Juniarti ,2014) Investor yang menilai rendah perusahaan keluarga maka akan meningkatkan cost of equity perusahaan. Rebecca dan Siregar (2012) menemukan bahwa kepemilikan keluarga ini memiliki pengaruh yang signifikan positif terhadap cost of equity perusahaan.

Kepemilikan keluarga menurut Rebecca dan Siregar (2012) adalah kepemilikan dari individu dan kepemilikan dari perusahaan tertutup (di atas 5\%), yang bukan perusahaan publik, negara, ataupu institusi keuangan. Aripin (2015) menyatakan bahwa perusahaan yang dimiliki oleh keluarga jika keluarga merupakan controlling shareholder atau memiliki saham minimal 20\% dari voting rights dan merupakan pemilik saham tertinggi dibandingkan shareholders lainnya.Dalam penelitian ini, peneliti akan menggunakan kriteria perusahaan keluarga seperti yang digunakan oleh Rebecca dan Siregar (2012). Untuk analisis sensitivitas, kepemilikan keluarga akan diukur dengan persentase kepemilikan keluarga. PSAK 15 (revisi 2009) yang menyatakan jika investor memiliki, 
secara langsung maupun tidak langsung 20\% atau lebih hak suara investee, maka investor dianggap mempunyai pengaruh signifikan dalam pengambilan keputusan perusahaan. Analisis ini bertujuan untuk mengetahui apakah ada atau tidaknya pengaruh signifikan oleh kepemilikan keluarga yang mempengaruhi besarnya cost of equity perusahaan (Rebecca dan Siregar, 2012).

\section{Kualitas Laba}

Laba yang terdapat dalam laporan keuangan seringkali dikaitkan dengan nilai saham di pasar modal dan digunakan investor untuk mengambil keputusan investasi. Informasi laba perusahaan dipakai oleh investor untuk menilai kinerja perusahaan. Schipper dan Vincent (2003) dalam Khikmah dan Pramita (2015), terdapat tiga sifat sebagai dasar pengukuran konstruk kualitas laba yaitu runtut waktu, karakteristik kualitatif, dan hubungan antara pendapatan, kas dan akrual. Sifat runtut waktu laba meliputi persistensi, prediktabilitas dan variabilitas. Menurut Dechow et al (2002) dalam Khikmah dan Pramita (2015) bahwa kualitas laba (earning quality) yang tinggi akan menyediakan informasi yang lebih banyak mengenai informasi mengenai kinerja perusahaan yang relevan untuk pengambilan keputusan. Terdapat tiga fokus dalam kualitas laba yaitu : pertama, kualitas laba bersifat kondisional dan bergantung pada relevansi pengambilan keputusan. Kedua, kualitas laba yang dilaporkan bergantung pada nilai laba dapat mencerminkan informasi kinerja keuangan perusahaan, ketiga, kualitas laba merupakan hasil pengabungan antara relevansi informasi yang dilaporkan terhadap keputusan yang dibuat dan kemampuan sistem akuntansi untuk mengukur peforma perusahaan (Paramita, 2012).

Menurut Dechow, et al. (2002) dalam Khikmah dan Pramita (2015) bahwa perusahaan yang memiliki kinerja kurang baik melakukan taktik akuntansi yang dapat meningkatkan laba sehingga membuat kualitas laba menjadi lebih rendah. Perusahaan yang sudah beroperasi lebih dari setahun, kinerja dapat dilihat dari tiga komponen yaitu arus kas, present value arus kas dimasa depan, dan present value untuk nilai likuidasi aset bersih. Oleh karena itu kualitas laba sangat mempengaruhi cost of equity perusahaan.

\section{PENGEMBANGAN HIPOTESIS}

KAP dalam menghadapi persaingan pasar dan mengembangkan sumber daya manusianya dengan memiliki spesialisasi industri auditor.Menurut Fernando, et al. (2006) spesialisasi industri auditor memungkinkan melindungi reputasinya dengan memberikan jaminan reputasi atas hasil audit yang dikerjakannya. Asimetri laporan keuangan untuk perusahaan yang diaudit oleh auditor spesialis akan lebih rendah dibandingkan perusahaan yang diaudit dengan auditor non-spesialis (umum) (Hajiha dan Sobhani, 2012).

Penelitian Fernando, et al. (2006) bahwa spesialisasi industri auditor menurunkan cost of equitydari klien perusahaan. Jadi penggunaan auditor spesialisasi industri dikaitkan dengan cost of equity yang lebih rendah untuk klien audit. Kemampuan untuk memiliki pengetahuan yang jauh lebih banyak terhadap klien (client specific knowledge) dan industri sangat penting untuk mendeteksi kesalahan atau salah saji laporan keuangan pada industri tertentu. Hal ini berarti bahwa auditor dengan spesialisasi industri mampu meningkatkan informasi dengan lebih akurat, sehingga mengurangi resiko informasi yang dihadapi oleh investor. Oleh karena itu cost of equity, termasuk di dalamnya cost of equitymenjadi berkurang. Berdasarkan argumentasi di atas, maka hipotesis yang akan diuji adalah:

H1: Spesialisasi industri auditor berpengaruh negatif terhadap cost of equity. 
KAP Big 4 membedakan dirinya dengan auditor yang lain dengan cara berinvestasi lebih pada reputasi modalnya dan dipandang sebagai penyedia kualitas audit yang lebih tinggi berdasarkan kompetensinya dan independensinya. Jasa audit yang disediakan oleh KAP dengan brand name (Big 8/Big 6/Big 5/Big 4) mendapat persepsi lebih dapat dipercaya oleh investor dibandingkan dengan auditor lainnya (Hajiha dan Sobhani, 2012). Menurut Khurana dan Raman (2004) menemukan bukti bahwa perusahaan yang menggunakan auditor Big $N$ memiliki cost of equity yang lebih rendah dibandingkan perusahaan yang menggunakan auditor Non Big N. Kualitas audit dari Big N memberikan kontribusi terhadap pengungkapan keuangan yang lebih dapat dipercaya daripada non Big $N$ terhadap kontrak-kontrak yang dibuat oleh perusahaan. Keandalan informasi keuangan tersebut akhirnya memberikan biaya yang lebih rendah bagi investor, sehingga mengurangi cost of equity. Dengan argumentasi di atas maka hipotesis yang akan diuji adalah:

\section{H2: Ukuran KAP berpengaruh negatif terhadap cost of equity.}

Audit tenure adalah masa jabatan dari Kantor Akuntan Publik (KAP) dalam memberikan jasa audit terhadap kliennya. Menurut Zohreh dan Neda (2012) menunjukan bahwa perusahaan diaudit oleh KAP terbesar di Iran, audit tenure selama 4 tahun membuktikan bahwa cost of equity nya menurun. Terdapat dua asumsi dalam audit tenure yakni: pertama, jika masa jabatan KAP memberikan jasa audit kepada kliennya (tenure) lebih lama maka memungkinkan auditor untuk mendapatkan keahlian dan pengetahuan khusus mengenai perusahaan (operasi, sistem akuntansi, dan pengendalian internal) sehingga auditor dapat mendeteksi salah saji material dengan baik. Pandangan pertama ini akan memberikan kualitas audit lebih tinggi. Kedua, tenure lebih lama maka dapat mengurangi kualitas audit karena mengarah ke kompromi sehingga independensi auditor dipertanyakan. Oleh karena itu, diperlukan batasan waktu KAP dalam memberikan jasa audit terhadap klien yang sama dengan waktu yang berturutturut.Dengan argumentasi di atas maka hipotesis yang akan diuji adalah:

\section{H3: audit tenure berpengaruh terhadap cost of equity.}

Di Indonesia perusahaan keluarga lebih banyak dibandingkan perusahaan nonkeluarga. Perusahaan keluarga didalamnya terdapat kontrol dan kendali dari pihak keluarga yang mendominasi. Kepemilikan keluarga yang besar inilah dapat menimbukan agency conflict diantara principal dan agent. Selain itu kepemilikan saham mayoritas oleh keluarga dapat menyebabkan agency problem diantara pemegang saham mayoritas dan pemegang saham minoritas. Menurut Dyck dan Zingales (2004) dalam Nugroho dan Meiranto (2014) adanya keluarga sebagai pemegang saham mayoritas akan memiliki kekuatan dan kontrol yang besar untuk menggunakan hal tersebut demi meningkatkan keuntungan pribadinya sehingga investor menginginkan tingkat pengembalian yang lebih tinggi untuk mengkompensasi resiko tersebut.Hasil penelitian Rebecca dan Siregar (2013) dan Amelia dan Yadnyana (2016) menunjukan hasil bahwa kepemilikan keluarga berpengaruh positif secara signifikan terhadap cost of equity. Perusahaan dengan kepemilikan keluarga, risiko informasi juga cenderung lebih tinggi dan berdampak negatif terhadap nilai perusahaan dan mengakibatkan cost of equity menjadi lebih tinggi (Amelia dan Yadnyana, 2016).Dengan argumentasi di atas maka hipotesis yang akan diuji adalah:

\section{H4: Semakin besarnya persentase Kepemilikan Keluarga berpengaruh positif terhadap cost of equity.}


Menurut Francis et al. (2004) dalam Khikmah dan pramita (2015), bahwa kualitas laba memiliki peran untuk mengurangi cost of equity. Semakin tingginya kualitas laba maka semakin rendah cost of equity. Penerapan corporate governance yang lebih baik akan menghasilkan cost of equity yang lebih rendah melalui pengurangan biaya monitoring yang dilakukan oleh investor. Hal ini disebabkan investor harus mengeluarkan biaya monitoring untuk memastikan hasil yang diberikan oleh manajemen perusahaan akibat adanya asimetri informasi.

Beberapa bukti empiris, antara lain penelitian Francis et al. (2008), Gray et al (2009) dan Bhattacharya et al. (2012) menunjukkan kualitas laba berdampak langsung pada penurunan nilai cost of equity suatu perusahaan. Semakin laba perusahaan berkualitas, maka perusahaan tidak banyak mengeluarkan biaya untuk memperoleh dana investasi atau operasi (cost of equity). Sebaliknya, semakin laba perusahaan tidak berkualitas maka akan meningkatkan cost of equity yang harus ditanggung perusahaan. Manajemen laba yang tinggi menyebabkan kualitas labanya menjadi rendah dan cost of equity menjadi tinggi (khikmah dan pramita, 2015). Manajemen laba yang tinggi menyebabkan earning quality menjadi rendah dan cost of equity nya menjadi tinggi. Dengan argumentasi di atas maka hipotesis yang akan diuji adalah:

\section{H5: Kualitas laba berpengaruh negatif terhadap cost of equity.}

\section{METODE PENELITIAN}

\section{Sample Penelitian}

Sampel adalah sekumpulan data yang diambil dari populasi. Pengambilan sampel dilakukan dengan metode purposive sampling dengan tujuan untuk mendapatkan sampel yang representatif sesuai dengan kriteria yang ditentukan. Kriteria yang ditentukan sebagai berikut:

a. Perusahaan yang sudah go public atau terdaftar di Bursa Efek Indonesia (BEI). Sample perusahaan yang diambil selama periode 2011-2015 kecuali sektor industri keuangan. Hal ini dikarenakan perusahaan dalam institusi keuangan dan asuransi memiliki karakteristik akrual yang berbeda.

b. Laporan keuangan perusahaan bisa diakses dari sumber yang digunakan.

c. Perusahaan memiliki kelengkapan data yang dibutuhkan. Perusahan yang tidak memiliki kelengkapan data akan dikeluarkan dari sampel.

\begin{tabular}{|l|c|c|c|c|c|c|}
\hline \multicolumn{1}{|c|}{ Kriteria Pengambilan Sampel } & $\mathbf{2 0 1 1}$ & $\mathbf{2 0 1 2}$ & $\mathbf{2 0 1 3}$ & $\mathbf{2 0 1 4}$ & $\mathbf{2 0 1 5}$ & Total \\
\hline Jumlah perusahaan yang terdaftar di BEI & 450 & 469 & 494 & 511 & 533 & 2457 \\
\hline $\begin{array}{l}\text { Perusahaan dengan sektor industri } \\
\text { keuangan }\end{array}$ & $(72)$ & $(74)$ & $(81)$ & $(87)$ & $(86)$ & $(400)$ \\
\hline $\begin{array}{l}\text { Perusahaan yang tidak memiliki } \\
\text { kepemilikan saham keluarga }\end{array}$ & $(248)$ & $(252)$ & $(258)$ & $(295)$ & $(284)$ & $(1,339)$ \\
\hline Total Sampel & 130 & 143 & 155 & 129 & 163 & 720 \\
\hline
\end{tabular}




\section{Jenis dan Sumber Data Penelitian}

Jenis data yang digunakan adalah data sekunder yang didapat dari annual report tahun 2011-2015. Data pendukung didapatkan dari fact book dan ICMD (Indonesia Capital Market Directory).

\section{Model Penelitian}

Model penelitian ini menggunakan analisis regresi berganda untuk menguji auditor spesialisasi industri, ukuran KAP, audit tenure, kepemilikan keluarga, dan kualitas laba terhadap cost of equity.

$$
\begin{gathered}
\text { COF }_{i t}=\alpha+\beta_{1} \text { SI }_{i t}+\beta_{2} U K_{i t}+\beta_{3} A T_{i t}+\beta_{4} K K_{i t}+\beta_{5} E O_{i t}+\beta_{6} \text { Size }_{i t}+\beta_{7} \text { Lev }_{i t} \\
+\beta_{8} \text { Prof }_{i t}+e
\end{gathered}
$$

Keterangan :

$\mathrm{COF}_{\mathrm{it}} \quad$ : cost of equity

$\beta_{1}-\beta_{5} \quad$ :Koefisien Regresi

SI it : Spesilissi Industri perusahaan i pada tahun t, Variabel dummy 1 jika perusahaan diaudit oleh auditor dengan spesialisasi dan 0 jika perusahaan diaudit oleh non auditor dengan spesialisasi.

$\mathrm{UK}_{\text {it }}$ : Ukuran KAP perusahaan i pada tahun t, Variabel dummy, 1 jika menggunakanjasa KAP Big 4 dan 0 jika menggunakan jasa KAP non Big 4.

$\mathrm{AT}_{\mathrm{it}} \quad$ : Audit tenure dalam perusahaan i pada tahun t. Jangka waktu perikatan diukur dengan jumlah angka tahun perusahaan melakukan perikatan dengan KAP yang sama pada tahun 2011-2015 secara berturut-turut.

$\mathrm{KK}_{\text {it }}$ : Variabel kepemilikan keluarga menggunakan persentase kepemilikan saham keluarga.

$\mathrm{EQ}_{\text {it }} \quad$ : Kualitas Labadalam perusahaan i pada tahun $\mathrm{t}$

Size $_{\text {it }}$ : Ukuran perusahaan i pada tahun $\mathrm{t}$

Lev it : Leverage perusahaan i pada tahun $\mathrm{t}$

Prof ${ }_{\text {it }} \quad$ : Profitabilitas perusahaan i pada tahun $\mathrm{t}$

e : error

\section{Definisi Operasional dan Pengukuran Variabel}

\section{a) Cost of Equity}

Cost of equity merupakan variabel dependen. Dalam penelitian ini cost of equity diukur dengan Eearning Price Ratio (EPR). Pendekatan ini digunakan Hajiha dan Sobhani (2012) dan Desiliani (2014) karena lebih sering digunakan untuk memperkirakan return dan nilai pasar saham di pasar modal. Perhitungan EPR menggunakan perusahaan dengan laba yang positif karena investor menghitung return apabila menginvestasikan dana di perusahaan tersebut. Investor akan tertarik pada EPR yang kecil karena laba per lembar saham lebih tinggi dibandingkan harga sahamnya serta payback period nya lebih singkat. Oleh karena itu pendekatan untuk cost of equity menggunakan EPR karena lebih bisa memperhitungkan penilaian investor terhadap kinerja perusahaan.

Perhitungan cost of equity dengan EPR sebagai berikut :

$$
\text { EarningPriceRatio }=\frac{\text { EarningperShare }}{\text { Harga Saham }}
$$




\section{b) Auditor Spesialisasi Industri}

Auditor spesialisasi industri merupakan variabel independen. Auditor spesialis indutri diukur dengan cara yang digunakan oleh Craswell et al. (1995) dalam Andreas (2012). Pertama, sampel industri yang digunakan adalah indutri yang minimal memiliki 30 perusahaan. Kedua, auditor dikatakan spesialis jika auditor tersebut mengaudit $20 \%$ dari total perusahaan yang ada dalam industri tersebut. Dalam penelitian ini, Kirana (2013) auditor spesialisasi industri diidentifikasi dengan market share dalam industri yang sama yaitu berdasarkan persentase total aset klien yang diaudit dalam suatu industri. Perhitungan auditor spesialis indutrisebagai berikut :

Auditor Spesialisai Industri $=\frac{\text { Total aset klien KAP pada industri tertentu }}{\text { Total aset klien pada industri tersebut }} \times 100 \%$

Dimana Kantor Akuntan Publik (KAP) yang memiliki lebih dari 20\% market share di industri tertentu maka diklasifikasikan sebagai spesialis industri untuk industri tertentu. Variabel ini diukur dengan varibel dummy. Angka 1 untuk perusahaan yang diaudit oleh auditor spesialisasi industri dan angka 0 untuk perusahaan yang diaudit oleh auditor non spesialisasi industri.

\section{c) Ukuran KAP}

Ukuran KAP merupakan variabel independen. Ukuran KAP menunjukkan kemampuan auditor untuk bersikap independen dan melaksanakan audit secara profesional, sebab KAP menjadi kurang tergantung secara ekonomi kepada klien. Diukur dengan menggunakan variable dummy $=1$ jika perusahaan diaudit oleh kantor akuntan yang berfiliasi dengan KAP Big 4 dan $=0$ jika tidak.

\section{d) Audit Tenure}

Audit tenure merupakan variabel independen. Putri dan Cahnoyowati (2012) Audit tenure adalah jangka waktu perikatan yang terjalin antara KAP dengan auditee yang sama. Audit tenure merupakan angka jumlah tahun berturut-turut patner bertanggung jawab atas pelaksanaan audit suatu kliennya dapat dilihat pada annual report perusahaan periode 2011 - 2015.

\section{e) Kepemilikan Keluarga}

Kepemilikan keluarga merupakan variabel independen. Dalam penelitian ini kepemilikan keluarga akan diukur dengan persentase kepemilikan keluarga dalam struktur saham dan adanya informasi hubungan afiliasi (dewan direksi dan komisaris) perusahaan. Selain itu status kepemilikan keluarga dapat dilihat dari susunan dewan direksi dan komisaris yang memiliki nama keluarga yang sama. Besarnya kepemilikan dapat dilihat dari kepemilikan modal saham. Semakin besarnya kepemilikan saham yang dimiliki oleh keluarga maka perusahaan akan semakin memiliki cost of equity yang tinggi pula. Analisis ini bertujuan untuk mengetahui ada atau tidak pengaruh (hak suara) oleh kepemilikan keluarga yang mempengaruhi besarnya cost of equity.

\section{f) Kualitas Laba}

Kualitas laba merupakan variabel independen Kualitas laba diukur dengan menggunakan proksi manajamen laba (Utami, 2014). Nilai manajemen laba yang tinggi mengakibatkan kualitas labanya rendah. Manajemen laba (DACC) diukur melalui discretionary accruals yang dihitung dengan cara menselisihkan total 
accruals (TACC) dan nondiscretionary accruals (NDACC). Perhitungan manajemen laba menggunakan Modified Jones Model sebagai berikut:

- Menghitung nilai total accruals yang diestimasi

$$
\frac{\mathrm{TA}_{\mathrm{it}}}{\mathrm{A}_{\mathrm{it}-1}}=\alpha_{1} \frac{1}{\mathrm{~A}_{\mathrm{it}-1}}+\beta_{1}\left(\frac{\Delta \mathrm{Rec}_{\mathrm{it}}}{\mathrm{A}_{\mathrm{it}-1}}\right)+\beta_{2}\left(\frac{\mathrm{PPE}_{\mathrm{it}}}{\mathrm{A}_{\mathrm{it}-1}}\right)+\epsilon_{\mathrm{it}}
$$

- Menghitung nilai non-discretionary accruals

$$
\mathrm{NDA}_{\mathrm{it}}=\alpha_{1} \frac{1}{\mathrm{~A}_{\mathrm{it}-1}}+\beta_{1}\left(\frac{\Delta \text { Sales }_{\mathrm{it}}-\Delta \mathrm{Rec}_{\mathrm{it}}}{\mathrm{A}_{\mathrm{it}-1}}\right)+\beta_{2}\left(\frac{\mathrm{PPE}_{\mathrm{it}}}{\mathrm{A}_{\mathrm{it}-1}}\right)+\epsilon_{\mathrm{it}}
$$

- Menghitung discretionary accruals

Keterangan:

$$
\mathrm{DA}_{i t}=\frac{T A_{i t}}{A_{i t-1}}-N D A_{i t}
$$

TA $_{\text {it }}$ : Total akrual perusahaan i pada periode $\mathrm{t}$

$\mathbf{D A}_{\mathrm{it}}$ : Discretionary accrual perusahaan i pada periode $\mathrm{t}$

NDA $_{i t}$ : Nondiscretionary accrual perusahaan i pada periode $\mathrm{t}$

$\mathbf{N I}_{\text {it }}$ : Net income perusahaan i pada periode $\mathrm{t}$

CFO $_{\text {it }}$ : Cash Flow Operating perusahaan i pada periode $\mathrm{t}$

$\mathbf{A}_{\text {it-1 }} \quad$ : Total aktiva pada periode t-1

$\Delta$ Sales $_{\text {it }}$ : Selisih sales perusahaan i pada periode $\mathrm{t}$

$\Delta \mathbf{R e c}_{\mathbf{i t}}$ : Selisih receivable perusahaan i pada periode $\mathrm{t}$

$\mathbf{P P E}_{\mathbf{i t}}$ : Nilai aktiva tetap perusahaan i pada periode $\mathrm{t}$

$\mathbf{\epsilon}_{\text {it }} \quad$ : Error

Jika nilai discretionary accrual yang semakin kecil maka kualitas laba yang disajikan oleh perusahaan semakin berkualitas. Semakin tinggi nilai dari discretionary accrual maka kualitas labanya semakin rendah, dan berarti laba dari perusahaan kurang bisa dipercaya karena laba tersebut dapat berasal dari aktivitas non riil.

\section{g) Ukuran Perusahaan}

Ukuran perusahaan merupakan variabel kontrol. Penelitian mengenai ukuran perusahaan dengan cost of equity. Jumlah aset yang besar akan memiliki kemampuan untuk memenuhi kewajiban di masa depan dan memberikan tingkat return yang lebih pasti terhadap investor. Karena perusahaan dapat memberikan deviden yang lebih besar.Semakin besar aset maka semakin besar pula modal yang perlu ditanam. Dalam penelitian ini ukuran perusahaan dinilai dengan log of total assets. Log Of Total Assets ini digunakan untuk mengurangi perbedaan signifikan antaraukuran perusahaan yang terlalu besar dengan ukuran perusahaan yang terlalu kecil.

\section{h) Leverage}

\section{$\mathrm{SIZE}=\log$ of total assets}

Leverage merupakan variabel kontrol. Leverage (LEV) diukur dengan rasio total utang dengan total aset. (Putri dan Cahyonowati, 2014). Rasio ini menunjukan seberapa besar aset perusahaan yang berasal dari utang. Leverage diduga dapat mempengaruhi cost of equity karena rasio ini dapat menilai dampak dari utang kepada kinerja perusahaan.Meningkatnya tingkat utang akan menambah risiko keuangan sehingga investor menilai perusahaan itu rendah dan meningkatkan cost of equity. 


$$
\boldsymbol{L E} \boldsymbol{V}=\frac{\text { TotalUtang }}{\text { TotalAset }}
$$

\section{i) Profitabilitas}

Profitabilitas merupakan variabel kontrol. Probabilitas sebagai sejauh mana perusahaan menghasilkan laba dari penjualan dan investasi perusahaan. Profitabilas merupakan gambaran dari kinerja manajemen dalam mengelola perusahaan (Paramita, 2012). Apabila profitabitas perusahaan baik maka para stakeholders yang terdiri dari kreditur, supplier, dan juga investor akan melihat sejauh mana perusahaan dapat menghasilkan laba dari penjualan dan investasi perusahaan. Dengan baiknya kinerja perusahaan akan meningkatkan nilai dan mengurangi cost of equity perusahaan. Dalam penelitian ini profitabilitas diukur menggunakan rasio return on asset (ROA). Semakin tinggi ROA maka resiko perusahaan semakin kecil, sehingga cost of equity perusahaan semakin rendah pula.

$$
\boldsymbol{R O A}=\frac{\text { Lababersih }}{\text { Jumlahasetperusahaan }}
$$

\section{HASIL DAN PEMBAHASAN}

\section{Statistik Deskriptif}

Analisis statistik deskriptif ini dilakukan untuk mengetahui jumlah data, nilai minimum dan maksimum dari viriabel yang ada dalam penelitian ini. Jumlah data awal sebanyak 720 tetapi tidak lolos uji normalitas, maka dilakukan penghapusan data yang ekstrim. Data akhir menjadi 630.

Tabel 4.1

Statistik Deskriptif

\begin{tabular}{|c|c|c|c|c|c|}
\hline Variabel & $\mathbf{N}$ & Minimum & Maksimum & Rata-Rata & $\begin{array}{c}\text { Std. } \\
\text { Deviasi }\end{array}$ \\
\hline Cost_of_Equity & 630 & -0.36 & 0.48 & 0.06 & 0.08 \\
\hline Auditor_SI & 630 & 0.00 & 1.00 & 0.22 & 0.42 \\
\hline Ukuran_KAP & 630 & 0.00 & 1.00 & 0.52 & 0.50 \\
\hline Audit_Tenure & 630 & 1.00 & 6.00 & 3.17 & 1.60 \\
\hline Kep_Kel & 630 & 0.00 & 86.72 & 17.38 & 23.70 \\
\hline Kualitas_Laba & 630 & -1.97 & 0.57 & -0.09 & 0.20 \\
\hline Ukuran_Perusahaan & 630 & 9.99 & 13.96 & 12.28 & 0.69 \\
\hline Leverage & 630 & 0.00 & 2.40 & 0.47 & 0.22 \\
\hline Profitabilitas & 630 & -0.21 & 0.35 & 0.05 & 0.06 \\
\hline
\end{tabular}

Berdasarkan tabel 4.1 variabel cost of equity diukur dengan laba per lembar saham dibagi dengan harga saham yang nilainya memiliki rata-rata sebesar 0.06 dan standar deviasinya sebesar 0,08 . Sedangkan untuk nilai minimumnya adalah -0.36 dan nilai maksimumnya sebesar 0.48 . Rata-rata sebesar $6 \%$ tergolong rendah yang berarti pasar menilai sesuai dengan kinerja perusahaan yang sesungguhnya. 
Tabel 4.2

Tabel Frekuensi

Auditor_spesialisasi_Industri

\begin{tabular}{|l|r|r|r|r|}
\hline & Frequency & Percent & \multicolumn{1}{|c|}{$\begin{array}{c}\text { Valid } \\
\text { Percent }\end{array}$} & $\begin{array}{c}\text { Cumulative } \\
\text { Percent }\end{array}$ \\
\hline Valid non spesialisasi & 490 & 77.8 & 77.8 & 77.8 \\
spesialisasi & 140 & 22.2 & 22.2 & 100.0 \\
Total & 630 & 100.0 & 100.0 & \\
\hline
\end{tabular}

Variabel auditor spesialisasi industri diukur dengan menggunakan variabel dummy dengan nilai 0 jika perusahaan yang diaudit oleh auditor non spesialisasi. Sedangkan nilai 1 untuk perusahaan yang diaudit oleh auditor dengan spesialisasi. Auditor dikatakan spesialis jika memiliki market share dalam industri yang sama lebih dari $20 \%$. Dari tabel 4.2 menunjukkan perusahaan yang diaudit oleh auditor spesialisasi industri hanya $22.2 \%$ sebanyak 140 perusahaan. Sedangkan sebesar 77.8\% atau 490 perusahaan diaudit oleh auditor non spesialisasi. Semakin auditor memiliki spesialisasi terhadap industri tertentu maka laba yang dihasilkan oleh kinerja perusahaan semakin berkualitas.

Tabel 4.3. Tabel Frekuensi

Ukuran KAP

\begin{tabular}{|l|r|r|r|r|}
\hline & Frequency & Percent & $\begin{array}{c}\text { Valid } \\
\text { Percent }\end{array}$ & $\begin{array}{c}\text { Cumulative } \\
\text { Percent }\end{array}$ \\
\hline Valid non Big 4 & 305 & 48.4 & 48.4 & 48.4 \\
Big 4 & 325 & 51.6 & 51.6 & 100 \\
Total & 630 & 100 & 100 & \\
\hline
\end{tabular}

Selain variabel auditor spesialisasi industri, variabel ukuran KAP juga menggunakan variabel dummy dengan nilai 0 jika perusahaan yang diaudit oleh KAP yang berafiliasi nonBig 4. Sedangkan nilai 1 untuk perusahaan yang diaudit oleh KAP yang berafiliasi Big 4. Tabel 4.3 menunjukkan perusahaan yang diaudit oleh KAP yang berafiliasi Big 4 sebanyak 51.6\% atau 325 perusahaan. Sedangakan sebesar $48.4 \%$ atau 305 perusahaan diaudit oleh KAP yang berafiliasi non Big 4. Variabel ini memiliki standar deviasi sebesar 0,5 .

Variabel audit tenure diukur dengan jumlah angka tahun perusahaan melakukan perikatan dengan KAP yang sama pada tahun 2011-2015 secara berturut-turut. PMK Nomor: 17/PMK.01/2008 menjelaskan bahwa pemberian jasa audit umum atas laporan keuangan dari suatu entitas dilakukan oleh KAP paling lama untuk 6 tahun buku berturutturut.Variabel ini memiliki standar deviasi sebesar 1,6. Nilai rata-rata 3,17 yang menunjukan bahwa audit tenure tidak melangar peraturan pemerintah karena dibawah 6 tahun berturut-turut.

Variabel selanjutnya yaitu kepemilikan keluarga, menggunakan persentase kepemilikan keluarga didalam perusahaan. Berikut merupakan hasil variabel kepemilikan keluarga : 
Tabel 4.4

Tabel Frekuensi

Audit tenure

\begin{tabular}{|r|r|r|r|r|}
\hline & Frequency & Percent & $\begin{array}{c}\text { Valid } \\
\text { Percent }\end{array}$ & $\begin{array}{c}\text { Cumulative } \\
\text { Percent }\end{array}$ \\
\hline Valid 1 & 109 & 17.3 & 17.3 & 17.3 \\
2 & 148 & 23.5 & 23.5 & 40.8 \\
3 & 118 & 18.7 & 18.7 & 59.5 \\
4 & 106 & 16.8 & 16.8 & 76.3 \\
5 & 79 & 12.5 & 12.5 & 88.9 \\
6 & 70 & 11.1 & 11.1 & 100.0 \\
Total & 630 & 100.0 & 100.0 & \\
\hline
\end{tabular}

Tabel 4.5

Tabel Frekuensi

\begin{tabular}{|c|c|c|c|}
\hline Kepemilikan Keluarga & $\begin{array}{c}\text { Jumlah } \\
\text { Perusahaan }\end{array}$ & Persentase & $\begin{array}{c}\text { Persentase } \\
\text { Kumulatif }\end{array}$ \\
\hline Dibawah $20 \%$ & 427 & 70.9 & 67.8 \\
\hline $21 \%-30 \%$ & 40 & 7.2 & 74.1 \\
\hline $31 \%-40 \%$ & 25 & 4.5 & 78.1 \\
\hline $41 \%-50 \%$ & 20 & 3.5 & 91.3 \\
\hline $51 \%-60 \%$ & 60 & 10.3 & 96.3 \\
\hline $61 \%-70 \%$ & 35 & 6.5 & 98.4 \\
\hline $71 \%-80 \%$ & 13 & 2.3 & 100 \\
\hline $81 \%-100 \%$ & 630 & 1.8 & \\
\hline Jumlah & & & \\
\hline
\end{tabular}

Dari tabel 4.5 dapat dilihat bahwa kepemilikan keluarga dengan sampel 630 mayoritas dibawah $20 \%$ dengan jumlah perusahaan sebanyak 427. Kepemilikan saham keluarga diatas 50\% artinya kepemilikan perusahaan mayoritas dimiliki oleh keluarga tertentu. Variabel ini memiliki standar deviasi sebesar 23.70 dan rata-rata 17.38 berarti mayoritas saham tidak dimiliki oleh keluarga.

Variabel kualitas laba diukur dengan discretionary accrual. Rata-rata sebesar 0.09. Nilai terendah untuk kualitas laba sebesar -1.97 dan nilai tertinggi dari kualitas laba sebesar 0.57. Variabel ini memiliki standar deviasi sebesar 0.20. Nilai discretionary accrual negatif berarti semakin tinggi kualitas laba. Laba yang di sajikan oleh perusahaan dalam sample penelitian ini merupakan laba yang dapat dipercaya oleh investor karena berasal dari aktivitas riil perusahaan.

Penelitian ini menggunakan variabel kontrol yaitu ukuran perusahaan, leverage, dan profitabilitas. Variabel ukuran perusahaan memiliki rata-rata sebesar 12,28. Ukuran perusahaan yang memiliki rata-rata sebesar 12,28 berarti perusahaan tersebut tidak 
mengalami masalah keuangan dalam menjalankan kegiatan operasional dan mampu memberikan deviden kepada investor yang lebih besar. Variabel leverage memiliki ratarata sebesar 0.4665. Artinya setiap 1 Rupiah aset digunakan untuk menjamin 0.47 rupiah hutang. Nilai minimum sebesar 0 dannilai maksimumnya sebesar 2.40. Variabel ini memiliki standar deviasi sebesar 0.22. Profitabilitas juga merupakan variabel kontrol dalam penelitian ini. Variabel ini memiliki nilai rata-rata sebesar 0.05. Nilai minimum sebesar -0.21 dan nilai maksimumnya sebesar 0,35 . Variabel ini memiliki standar deviasi sebesar 0.06 .

\section{Analisis Dan Pembahasan}

\section{Uji Normalitas}

Uji normalitas dilakukan untuk mengetahui apakah data yang telah ditentukan terdistribusi normal atau tidak. Pengujian dalam penelitian ini menggunakan uji kolmogorof-smirnov dimana ketentuan uji ini jika nilai dari sig lebih dari sama dengan 0,05 maka data terdistribusi secara normal. Jika nilai signifikansinya kurang dari 0,05 maka data tidak terdistribusi secara normal maka harus dilakukan proses penormalan dengan menghapus data outliner. Berikut adalah hasil uji normalitas :

Tabel 4.6

Tabel Uji Normalitas

\begin{tabular}{|c|c|c|}
\hline Unstandarized Residual & Kolmogorov-Smirnov & Shapiro Wilk \\
\hline Statistik & 0.224 & 0.56 \\
\hline Jumlah Data & 720 & 720 \\
\hline Signifikansi & 0.000 & 0.000 \\
\hline
\end{tabular}

Dari hasil pengujian normalitas bahwa nilai signifikansi sebesar 0.000 lebih kecil dari 0.05. Maka harus melakukan proses penormalan dengan menghapus data outliner.

Tabel 4.7

Tabel pengujian kembali Normalitas

\begin{tabular}{|c|c|c|}
\hline Unstandarized Residual & Kolmogorov-Smirnov & Shapiro Wilk \\
\hline Statistik & 0.032 & 0.994 \\
\hline Jumlah Data & 630 & 630 \\
\hline Signifikansi & 0.198 & 0.009 \\
\hline
\end{tabular}

Tabel 4.7 menunjukan nila signifikansinyasebesar 0,198. jadi, pada penelitian ini, dapat diketahui Asymp Sig untuk Standardized Residual yaitu sebesar 0,198 > 0.05. artinya, data residual penelitian ini terdistribusi normal.

\section{Uji Multikolinieritas}

Pengujian ini dilakukan dengan menganalisa collinearity statistics pada nilai tolerance dan nilai Variance Inflation Factor (VIF). Data tidak Multikolinearitas apabila nilai tolerance $>0,1$ dan $\mathrm{VIF}<10$. 
Tabel 4.8. Multikolonearitas

\begin{tabular}{|c|c|c|c|c|c|c|c|}
\hline \multirow{2}{*}{ MODEL } & \multicolumn{2}{|c|}{$\begin{array}{c}\text { Unstandardized } \\
\text { Coefficients }\end{array}$} & $\begin{array}{c}\text { Standardized } \\
\text { Coefficients }\end{array}$ & \multirow{2}{*}{$\mathrm{t}$} & \multirow{2}{*}{ Sig. } & \multicolumn{2}{c|}{$\begin{array}{c}\text { Collinearity } \\
\text { Statistics }\end{array}$} \\
\cline { 2 - 4 } \cline { 7 - 8 } & $\mathrm{B}$ & Std. Error & Beta & & & Tolerance & VIF \\
\hline (Constant) & 0.137 & 0.047 & & 2.897 & 0.004 & & \\
\hline Auditor_SI & -0.018 & 0.007 & -0.090 & -2.697 & 0.007 & 0.785 & 1.274 \\
\hline Ukuran_KAP & 0.000 & 0.006 & -0.004 & -0.107 & 0.915 & 0.692 & 1.445 \\
\hline Audit_tenure & 0.006 & 0.002 & 0.092 & 2.867 & 0.004 & 0.846 & 1.182 \\
\hline Kepemilikan_kel & -8.296 & 0.000 & -0.024 & -0.816 & 0.415 & 0.973 & 1.028 \\
\hline Kualitas_Laba & -5.833 & 0.000 & -0.012 & -4.955 & 0.000 & 0.989 & 1.011 \\
\hline Ukuran_per & -0.011 & 0.004 & -0.089 & -2.642 & 0.008 & 0.769 & 1.300 \\
\hline Leverage & 0.019 & 0.012 & -0.050 & -1.665 & 0.096 & 0.962 & 1.039 \\
\hline Profitabilitas & 0.956 & 0.043 & 0.665 & 22.041 & 0.000 & 0.964 & 1.038 \\
\hline
\end{tabular}

nilai VIF semua variabel tidak ada yang lebih besar dari pada 10. Jadi, dapat disimpulkan tidak ada korelasi yang kuat antar variabel atau tidak terjadi multikolinearitas.

\section{Uji Autokorelasi}

Pengujian Autokorelasi digunakan untuk melihat apakah ada korelasi diantara residual pada satu pengamatan dengan pengamatan lainnya yang terdapat pada model regresi. Pengujian ini menggunakan uji Durbin-Watson.

Tabel 4.9

Tabel Hasil Uji Autokorelasi

\begin{tabular}{|l|r|r|r|r|r|}
\hline Model & \multicolumn{1}{|c|}{$\mathrm{R}$} & R Square & $\begin{array}{c}\text { Adjusted R } \\
\text { Square }\end{array}$ & $\begin{array}{c}\text { Std. Error of } \\
\text { the Estimate }\end{array}$ & $\begin{array}{c}\text { Durbin- } \\
\text { Watson }\end{array}$ \\
\hline 1 & $0.675^{\mathrm{a}}$ & 0.456 & 0.449 & 0.06255 & 2.022 \\
\hline
\end{tabular}

Dari tabel 4.9 nilai Durbin Watson (DW) adalah 2,022. Nilai $\mathrm{DL}=1,845885$ nilai $\mathrm{DU}=$ 1,92576 dan 4-DU $=2,108755$ dengan $\mathrm{N}=630$ dan $\mathrm{K}=8$. Nilai $\mathrm{DW}$ sebesar 2,022 berada diantara $1,845885<\mathrm{DW}<(4-1,891245)$. Hasil pengujian ini yaitu dalam model regresi tidak ada autokorelasi.

\section{Uji Heterokedastisitas}

Berikut merupakan tabel hasil pengolahan uji heterokedastisitas pada model penelitian: 
Tabel 4.10

Tabel Hasil Uji Heterokedastisitas

\begin{tabular}{|c|c|c|c|c|c|}
\hline \multirow{2}{*}{ MODEL } & \multicolumn{2}{|c|}{$\begin{array}{c}\text { Unstandardized } \\
\text { Coefficients }\end{array}$} & $\begin{array}{c}\text { Standardized } \\
\text { Coefficients }\end{array}$ & Sig. \\
\cline { 2 - 5 } & B & Std. Error & & 1.721 & 0.086 \\
\hline (Constant) & 0.055 & 0.032 & -0.019 & -0.439 & 0.661 \\
\hline Auditor_SI & -0.002 & 0.005 & 0.121 & 1.415 & 0.160 \\
\hline Ukuran_KAP & 0.010 & 0.004 & -0.071 & -1.694 & 0.091 \\
\hline Audit_tenure & -0.002 & 0.001 & -0.064 & -1.637 & 0.102 \\
\hline Kepemilikan_kel & 0.000 & 0.000 & -0.035 & -0.900 & 0.368 \\
\hline Kualitas_Laba & -9.043 & 0.000 & -0.032 & -0.728 & 0.467 \\
\hline Ukuran_per & -0.002 & 0.003 & 0.158 & 0.707 & 0.480 \\
\hline Leverage & 0.031 & 0.008 & 0.173 & 0.182 & 0.856 \\
\hline Profitabilitas & 0.127 & 0.029 & & & \\
\hline
\end{tabular}

\section{Sumber : Data Sekunder yang diolah (2017)}

Hasil uji heterokedastisitas pada tabel 4.10 di atas menunjukan bahwa nilai signifikansi semua variabel lebih dari 0,05. Hal tersebut menunjukan bahwa tidak ada masalah heteroskedastisitas. Artinya semua variabel independen dalam penelitian ini memiliki variance yang sama.

\section{Pengujian Hipotesis}

Pengujian hipotesis dapat dilihat pada tabel 4.11 Variabel independen dianggap berpengaruh apabila nilai signifikansinya kurang dari 0,05 .

Tabel 4.11

Hasil Pengujian Hipotesis

\begin{tabular}{|c|c|c|c|c|c|c|c|}
\hline \multirow{2}{*}{ MODEL } & \multicolumn{2}{|c|}{$\begin{array}{c}\text { Unstandardized } \\
\text { Coefficients }\end{array}$} & $\begin{array}{c}\text { Standardized } \\
\text { Coefficients }\end{array}$ & $t$ & Sig. & $\begin{array}{c}\text { Sig. } \\
(\alpha / 2)\end{array}$ & Hasil \\
\cline { 2 - 7 } & B & Std. Error & Beta & & & & \\
\hline (Constant) & 0.137 & 0.047 & & 2.897 & 0.004 & 0.002 & \\
\hline Auditor_SI & -0.018 & 0.007 & -0.090 & -2.697 & 0.007 & 0.0035 & Diterima \\
\hline Ukuran_KAP & 0.000 & 0.006 & -0.004 & -0.107 & 0.915 & 0.458 & Ditolak \\
\hline Audit_tenure & 0.006 & 0.002 & 0.092 & 2.867 & 0.004 & 0.002 & Diterima \\
\hline Kepemilikan_kel & -8.296 & 0.000 & -0.024 & -0.816 & 0.415 & 0.208 & Ditolak \\
\hline Kualitas_Laba & -5.833 & 0.000 & -0.012 & -4.955 & 0.000 & 0.000 & Diterima \\
\hline Ukuran_per & -0.011 & 0.004 & -0.089 & -2.642 & 0.008 & 0.004 & Diterima \\
\hline Leverage & -0.019 & 0.012 & -0.050 & -1.665 & 0.096 & 0.048 & Diterima \\
\hline Profitabilitas & 0.956 & 0.043 & 0.665 & 22.041 & 0.000 & 0.000 & Diterima \\
\hline
\end{tabular}




\section{Dari tabel diatas dapat diperoleh hasil uji hipotesis yaitu :}

\section{Auditor Spesialisasi Industri}

Hipotesis pertama dalam penelitian ini yaitu auditor spesialisasi industri berpengaruh negatif terhadap cost of equity. Artinya semakin banyak perusahaan yang diaudit dengan KAP yang sama dalam suatu industri maka KAP tersebut menguasai industri tersebut. Dari hasil regresi yang telah dilakukan, koefisien auditor spesialisasi industri auditor adalah -0.090 dan nilai sig 0.0035 (kurang dari 0,05). Artinya auditor spesialisasi industri berpengaruh negatif secara signifikan terhadap cost of equity. Secara empiris, hipotesis pertama diterima.

Hasil penelitian ini mendukung hasil penelitian dari Hajiha dan Sobhani (2012) dan Herusetya (2012) yang menemukan bukti bahwa semakin spesialisasi industri auditor akan menambah kualitas audit sehingga berpengaruh negatif secara signifikan terhadap cost of equity. Dengan demikian, dapat disimpulkan bahwa auditor dengan spesialisasi industri berpengaruh terhadap kualitas audit yang diberikan sehingga dapat mengurangi cost of equity.

\section{Ukuran KAP}

Hipotesis kedua dalam penelitian ini yaitu ukuran KAP berpengaruh negatif terhadap cost of equity. Hal ini dikarenakan Kualitas audit yang diproksikan dengan ukuran KAP akan memberikan informasi yang berkualitas dan reliable sehingga investor tidak salah dalam pengambilan keputusan berinvestasi dan dapat menurunkan cost of equity.Dari hasil regresi yang telah dilakukan, koefisien regresi ukuran KAP yang berafiliasi Big 4 adalah -0,004 dan nilai sig 0,458 (lebih dari 0,05). Artinya ukuran KAP tidak berpengaruh terhadap cost of equity. Secara empiris, hipotesis kedua ditolak.KAP Big 4 dan non Big 4 tidak memiliki perbedaan kualitas audit sehingga informasi yang diperoleh investor dapat diandalkan untuk mengurangi resiko dalam pengambilan keputusan investasi.

\section{Audit Tenure}

Hipotesis ketiga dalam penelitian ini memprediksikan audit tenure berpengaruh terhadap cost of equity. Hipotesis ketiga ini tidak berarah karena ada perbedaan dari penelitian sebelumnya. Dari hasil regresi yang telah dilakukan, nilai signifikansinya 0,004 (dibawah 0,05) dan koefisien regresi audit tenure sebesar 0.092. Artinya audit tenure berpengaruh positif terhadap cost of equity. Semakin lama jangka waktu perikatan audit (audit tenure) maka dapat meningkatkan cost of equity perusahaan. Secara empiris, hipotesis ketiga diterima.Hal ini membuktikan bahwa semakin lamanya audit tenure yang terjalin antara perusahaan dan KAP dapat mengurangi kualitas audit karena mengarah ke kompromi sehingga independensi auditor dipertanyakan. Dengan begitu auditor dapat dapat meningkatkan kualitas audit sehingga informasi yang dihasilkan lebih berkualitas dan reliable. Sehingga kualitas audit yang diproksikan audit tenureberpengaruh positif secara signifikan terhadap cost of equity.

\section{Kepemilikan Keluarga}

Hipotesis keempat dalam penelitian ini memprediksikan semakin besar kepemilikan kepemilikan keluarga berpengaruh positif terhadap cost of equity. Dari hasil regresi yang telah dilakukan, nilai signifikansinya 0.208 (lebih dari 0,05) dan koefisien regresi kepemilikan keluarga sebesar -0.024. Artinya kepemilikan keluarga berpengaruh negatif tidak signifikan terhadap cost of equity. Secara empiris, hipotesis keempat ditolak.

Ada atau tidaknya kepemilikan keluarga dalam perusahaan tidak berpengaruh terhadap cost of equity karena mayoritas saham perusahaan tidak dimiliki oleh keluarga. 
Keputusan yang diambil manajemen perusahaan tidak didominasi oleh kepentingan keluarga tertentu terlebih untuk jumlah deviden yang akan dibagikan oleh pemegang saham. Perusahaan dengan kepemilikan keluarga akan mengutamakan keberlanjutan perusahaan dan berusahaan memberikan kinerja yang lebih baik agar dapat bersaing dengan industri sejenis.

\section{Kualitas Laba}

Hipotesis kelima dalam penelitian ini memprediksikan kualitas laba berpengaruh negatif terhadap cost of equity. Artinya semakin laba yang disajikan berkualitas maka cost of equity akan semakin rendah. Kualitas laba merupakan proksi dari tata kelola perusahaan.Dari hasil regresi yang telah dilakukan, nilai signifikansinya 0,000 (dibawah 0,05) dan koefisien regresi kualitas laba sebesar -0.012. Artinya kualitas laba berpengaruh negatif secara signifikan terhadap cost of equity. Semakin informasi laba itu berkualitas maka cost of equity akan semakin rendah. Secara empiris, hipotesis kelima diterima.

Kualitas laba berdampak langsung pada penurunan nilai cost of equity suatu perusahaan. Semakin laba perusahaan berkualitas, maka perusahaan tidak banyak mengeluarkan biaya untuk memperoleh dana investasi atau operasi. Sebaliknya, semakin laba perusahaan tidak berkualitas maka akan meningkatkan cost of equity yang harus ditanggung perusahaan.

\section{Variabel Kontrol}

Penelitian ini menggunakan tiga variabel kontrol yaitu ukuran perusahaan, leverage, dan profitabilitas. Nilai signifikansi ukuran perusahaan yaitu 0.004 lebih kecil dari 0,05. Hal ini menunjukan bahwa ukuran perusahaan berpengaruh terhadap cost of equity. Ukuran perusahaan (Size) merupakan tingkat identifikasi besar atau kecilnya suatu perusahaan. Ukuran perusahaan menjadi faktor dalam besar kecilnya cost of equity. Hasil penelitian ini konsisten dengan penelitian Paramita (2012) bahwa ukuran perusahaan berpengaruh terhadap cost of equity.

Selain ukuran perusahaan, variabel kontrol yang kedua yaitu leverage. Nilai signifikansi leverage yaitu 0,048 lebih kecil dari 0,05 dan koefisien regresi leverage sebesar -0,050. Artinya bahwa leverage berpengaruh negatif terhadap cost of equity. Hasil penelitian ini menunjukan bahwa Meningkatnya tingkat utang akan menambah risiko keuangan sehingga investor menilai perusahaan itu rendah dan meningkatkan cost of equity. Profitabilitas merupakan variabel kontrol yang ketiga. Berdasarkan hasil analisis regresi didapatkan nilai koefisien sebesar 0,665 dan nilai signifikansi 0.000 kurang dari dari 0,05 . Artinya bahwa profitabilitas berpengaruh positif terhadap cost of equity. Hasil penelitian ini mengindikasikan bahwa profitabilitas mampu mengendalikan variabel independen yang meliputi auditor spesialisasi industri, ukuran KAP, audit tenure, kepemilikan keluarga dan kualitas laba terhadap cost of equity.

\section{SIMPULAN}

Berdasarkan penelitian ini didapatkan kesimpulan sebagai berikut :

1. Kualitas audit yang diproksikan oleh auditor spesialisasi industri berpengaruh negatif terhadap cost of equity. Artinya perusahaan yang diaudit oleh KAP yang memiliki auditor spesialisasi industri memiliki cost of equity yang rendah.

2. Kualitas audit yang diproksikan oleh ukuran KAP tidak berpengaruh terhadap cost of equity. Secara empiris, hipotesis kedua ditolak.

3. Kualitas audit yang diproksikan oleh audit tenure berpengaruh signifikan terhadap cost of equity. Artinya jangka perikatan audit KAP dengan client dapat 
mempengaruhi besarnya cost of equity perusahaan. Secara empiris, hipotesis ketiga diterima.

4. Tata kelola perusahaan yang diproksikan oleh kepemilikan keluarga tidak berpengaruh terhadap cost of equity. Secara empiris, hipotesis keempat ditolak.

5. Kualitas laba berpengaruh negatif terhadap cost of equity. Artinya perusahaan yang memiliki kualitas laba yang tinggi akan memiliki cost of equity yang rendah. Secara empiris, hipotesis kelima diterima.

6. Variabel kontrol ukuran perusahaan,leverage berpengaruh negatif terhadap cost of equity. Sedangkan profitabilitas berpengaruh positif terhadap cost of equity.

Berdasarkan penelitian ini didapatkan Saran sebagai berikut :

1. Penelitian selanjutnya dapat menambah pengukuran lainnya seperti kepemilikan manajerial dan kepemilikan institusional.

2. Pengukuran variabel dependen yaitu cost of equity menggunakan earning price ratio (EPR). Penelitian selanjutnya dapat menggunakan pengukuran lainnya seperti model penilaian pertumbuhan konstan, capital asset pricing model (CAPM), dan model ohlsonsehingga kesimpulan dapat lebih menyakinkan pengguna informasi. 


\section{DAFTAR PUSTAKA}

Abdullah, F., Shah, A., Iqbal, A. M., Gohar, R., dand Farooq, M. 2011. The Effect of Family Ownership on Firm Performance: Empirical Evidence from Pakistan.

Adrianto dan Wibowo, B. 2007. Pengujian Teori Pecking Order Pada Perusahaanperusahaan Non Keuangan LQ45 Periode 2001-2005.

Amelia,V.R dan Yadnyana,I.K. 2016.Pengaruh Good Corporate Governance, Kepemilikan Keluarga dan Kepemilikan Institusional pada Biaya Ekuitas Perusahaan Manufaktur. E-Jurnal Akuntansi Universitas Udayana, Vol.16(2).hal 1264-1289.

Andreas Hans.2012. Spesialisasi Industri Auditor Sebagai Prediktor Earnings Response Coefficient Perusahaan Publik Yang Terdaftar di Bursa Efek Indonesia. Jurnal Akuntansi dan Keuangan 14 (2): 69-81.

Arens, A., Elder, R. and Beasley, M. 2008. Auditing and Assurance Services. 12th ed.,Pearson Prentice-Hall, Englewood Cliffs, NJ.

Aripin, Bustanul. 2015. Pengaruh Kepemilikan Keluarga, Kepemilikan Institusional, dan Kepemilikan Manajerial terhadap Biaya Utang. Skripsi. Universitas Islam Negeri Syarif Hidayatullah Jakarta.

Azizkhani, M., Monroe, G.S., and Shailer, G. 2013. Audit partner tenure and cost of equity capital. Journal of Practice \&Theory 32 1: 183-202.

Balsam, S., Krishnan, J., \& Yang, J. S. 2003. Auditor Industry Specialization and Earnings Quality. Auditing : A Journal of Practice and Theory, 22 (2): 71- 97.

Bamber, E.M \& Bamber, L.S. 2009. Discussion of mandatory audit rotation, audit quality and market perception: evidence from Taiwan, Contemporary Accounting Research, 26 (2): 392- 402.

Beasley, M.S. and Petroni, K.R. 2001. Independence and Auditor Selection. Journal of Accountancy 192: 86.

Ben-Nasr, H \& Al-Dakheel,A.H. 2015. The impact of earnings quality on the cost of equity: evidence from privatized firm. International Journal or Financial Research, 6 (1), hal.68-78.

Blackwell, D, T. Noland and D. Winters. 1998. The value of auditor assurance: evidence from loan pricing. Journal of Accounting Research 36: 57-70.

Botosan, A. Christine. 1997. Disclosure Level and The Cost of Equity Capital". Accounting Review. 72 (3): 323-349.

Brigham, Eugene F. dan Joel F. Houston. 2006. Dasar-dasar Manajemen Keuangan, Buku 2, Edisi 10, alih bahasa: Ali Akbar Yulianto. Jakarta: Penerbit Salemba Empat.

Butar Butar, S. 2014. Reputasi Auditor, Karakteristik Dewan Komisaris, Dan Keinformatifan Laba. Jurnal Akuntansi Bisnis 13 (2): 25-43

Butar Butar, S. 2016. Merger Auditor dan Kualitas Audit: Bukti Empiris Dari Bursa Efek Indonesia. Jurnal Ekonomi dan Bisnis 17 (2): 107-128. 
Craswell, A.T., Francis, J.R. \& Taylor, S.L. 1995.Auditor Brand Name Reputation and Industry Specialization. Journal of Accounting and Economics, 20, 297-322.

Dechow, Patricia M and Ilia D. Dichev. 2002. The quality of accruals and earnings: the role of accrual estimation errors. The Accounting Review 77: 35-59

Desiliani, Nabella. 2014. Pengaruh Ukuran Kantor Akuntan Publik, Spesialisasi Industri Auditor dan Audit Tenure pada Biaya Modal Ekuitas. Skripsi pada FEB UNDIP Semarang.

Dwi,P.Y.S.,Yuniarta,G.A.,dan Admadja. 2014. Pengaruh Struktur Modal, Pertumbuhan Perusahaan, dan Profitabilitas Terhadap Nilai Perusahaan. Jurusan Akuntansi S1.Vol. 2, No: 1, hal 1-10.

Dyck, A., dan L. Zingales. 2004. "Control Premiums And The Effectiveness of CorporateGovernance Systems. Journal of Applied Corporate Finance 16, 51-72.

Fernando, G.D., Elder, R.J., and Abdel-Meguid, A.M., 2006, "Audit Firm Size, Industry Specialization, Client Size, and Cost of Capital - Information and Monitoring Effects." Working paper, Syracuse University.

Fitriany,Sidharta,Dwi,dan Hilda.2015.Pengaruh Tenure, Rotasi dan Spesialisasi Kantor Akuntan Publik (KAP) terhadap Kualitas Audit: Perbandingan Sebelum dan Sesudah Regulasi Rotasi KAP di Indonesia. Jurnal Akuntansi dan Keuangan, Vol. 17, No. 1,Hal.12-28.

Ghozali, Imam. 2011. Aplikasi Analisis Multivariate dengan Program IBM SPSS 19. Semarang: Badan Penerbit Universitas Diponegoro.

Godfrey, J., A. Hodgson, S. Holmes, dan A. Tarca. 2006. Accounting Theory. Sixth Edition. Singapore: John Wiley \& Sons Australia.

Hajiha Zohreh dan Sobhani.2012.Audit Quality and Cost of Equity Capital:Evidence of Iran.International Research Journal of Finance and Economics 159-172.

Hardiningsih Pancawati.2010.Pengaruh Independensi, Corporate Governance, dan Kualitas Audit Terhadap Integritas Laporan Keuangan. Kajian Akuntansi 2 (1): 61-67.

Hermuningsih Sri.2012.Dampak Invesment Opportunity Set Terhadap Cost Of Equity Capital Dengan Diclosure Sebagai Variabel Mediasi. Doctoral Colloquium \& Conference FEB UGM, 28-29 November 2012.

Hermuningsih Sri.2013.Pengaruh Profitabilitas, Growth opportunity, Struktur Modal Terhadap Nilai Publik Di Indonesia. Buletin Ekonomi Moneter dan Perbankan, Hal 127-148.

Herusetya Antonius. 2012. Dapatkah Kualitas Audit Mengurang Biaya Modal Ekuitas Exante?.Jurnal Akuntansi Indonesia 16 (1): 48-61.

Hidayat T. 2012. Pengaruh Ukuran KAP dan Auditor Tenure Terhadap Value Relevance dari Nilai Wajar. Jurnal Akuntansi dan Keuangan Indonesia 9 (2): 171-189.

Hogan, C. E., and Jeter, D. C. 1999).Industry specialization by auditors. Auditing: A Journal of Practice dan Theory 18 (1): 1-17. 
Ibrahim, H., dan Samad, F. A. 2010. Family business in emerging markets: The case of Malaysia. African Journal of Business Management 4(13): 2586-2595.

Indrajaya G,Herlina, dan Setiadi R. 2011. Pengaruh Struktur Aktiva, Ukuran Perusahaan, Tingkat Pertumbuhan, Profitabilitas dan Risiko Bisnis Terhadap Struktur Modal.Jurnal Ilmiah Akuntansi. 6: 1-23.

International Auditing and Assurance Standards Board. 2009. International Standard on Auditing 220: Quality Control for an Audit of Financial Statement.

International Auditing and Assurance Standards Board. 2011. Audit quality: an IAASB perspective.

Jensen, M. C., and Meckling, W. H. 1976. Theory of the firm: managerial behavior, agency costs and ownership structure. Journal of Financial Economics 3 (4): 305-360.

Juniarti, dan F. Yunita. 2003. Pengaruh Tingkat Disclosure Terhadap Biaya Ekuitas. Jurnal Akuntansi dan Keuangan 5(2): 150-168.

Kementerian Keuangan RI. Peraturan Menteri Keuangan Republik Indonesia Nomor 17/PMK.01/2008. Tentang Jasa Akuntan Publik.

Khikmah,S.N,\&Pramita,Y.D. 2015. Pengaruh Kualitas Laba Terhadap Biaya Modal Ekuitas Dengan Asimetri Informasi Sebagai Variabel Mediasi. Laporan Penelitian Dosen Universitas Muhammadiyah, Magelang.

Khurana, I. K., \&Raman, K. K. 2004. Litigation risk and the financial reporting credibility of big 4 versus non big 4 audit: Evidence from Anglo American Countries. The Accounting Review 79 (2): 473-495.

Kirana, Pangestika A.J. 2013. Pengaruh Kualitas Audit Terhadap Cost Of Equity Capital. Skripsi pada FEB UNDIP Semarang.

Kusumawati IT.,dan Juniarti.2014. Pengaruh Family Control Terhadap Profitabilitas dan Nilai Perusahaan Pada Industri Dasar dan Kimia",Business Accounting Review 2(1):.170-180.

Lambert, R., C. Leuz, and Verrecchia. R. 2007. Accounting Information, Desclosure, and the Cost of Capital. Journal of Accounting Research 45(2): 385-420.

Leksmono, M. H. (2010). Pengaruh Managerial Ownership, Family Ownership, Firm Size, dan Firm Risk terhadap Firm Value. Unpublished undergraduate thesis, Universitas Sebelas Maret, Surakarta.

Mansi, S., W. Maxwell and D. Miller, 2004, "Does auditor quality and tenure matter to investors? Evidence from the bond market" Journal ofAccounting Research, 42, 4, pp. 755-793.

Nugroho, D. R dan Meiranto, W. 2014. Pengaruh Good Corporate Governance Terhadap Biaya Ekuitas dan Biaya Hutang. Diponegoro Journal Of Accounting 3 (3): 1-12.

Owhoso, V. E., Messier, W. F., Jr., \&Lynch, J. G. Jr. 2002. Error detection by industry specialized teams during sequential audit review. Journal of Accounting Research 40 (3): $883-900$. 
Paramita, Anisa Harini. 2012. Pengaruh Kualitas Audit Terhadap Manajemen laba Dan Cost Of Equity. Skripsi pada Fakultas Ekonomi Univesitas Indonesia, Depok.

Pittman, J. and S. Fortin, 2004. Auditor choice and cost of debt capital for newly public listed firms. Journal of Accounting and Economics 37 : 113-136.

Putri,T.M., dan Cahyonowati. 2014. Pegaruh Auditor Tenure, Ukuran Kantor Akuntan Publik, dan Ukuran Perusahaan Klien Terhadap Kualitas Audit.Diponegoro Journal of Accounting. 3 (2): 1-13.

Rebecca, Yulisa.,\& Siregar,S.V. 2013. Pengaruh corporate governance index, kepemilikan keluarga, dan kepemilikan institusional terhadap Biaya Ekuitas dan Biaya Utang. Jurnal Akuntansi Keuangan 11 (2): 88-100.

Schipper, Katherine and Linda Vincent. 2003. Earnings quality. Accounting Horizons Supplement: 97-110.

Sekaran, Uma. 2006b. Research Methods for Business. Edisi Empat. Buku 2. Terj. New York: John Wiley and Sons Inc.

Setyorini Dhtah,Rahmawati, Yusita, Dewanti, Hutama. 2015. Pengaruh Reputasi Auditor dan Tenur Audit Terhadap Cost Of Debt Capital. Working paper. Fakultas Ekonomi Universitas Negeri Yogyakarta.

Simunic, D. A., and Stein, M. T. 1987. Product differentiation in auditing: Auditor choice in the market for unreasoned new issues. Vancouver, BC: Canadian Certified General Accountants' Research Foundation.

Suparno, Deny. 2013. Analisis Hubungan Antara Atribut Kualitas Audit Dengan Biaya Ekuitas Modal. Skripsi pada FEB UNDIP Semarang.

Susanto, S and Siregar, S.V. 2011. Corporate Governance, Kualitas Laba, dan Biaya Modal Ekuitas : Studi Empiris Perusahaan Manufaktur di BEI tahun 2009. Tesis. Fakultas Ekonomi Universitas Indonesia.

Teoh, S. H., and Wong, T. J. 1993. Perceived auditor quality and theearnings response coefficient. The Accounting Review 68 (2): 346-366.

Utami, W. 2005. Pengaruh Manajemen Laba Terhadap Biaya Modal Ekuitas (Studi pada Perusahaan Manufaktur).Makalah dipresentasikan dalam Simposium Nasional Akuntansi VIII. 15 - 16. September: 100 - 116.

Villalonga, B. dan R. Amit. 2005. How do family ownership, control, and management affect firm value?. Journal of Financial Economics 80, 385-417.

Watts, R. L., and Zimmerman, J. L. 1983. Agency problems, auditing, and the theory of the firm: Some evidence. Journal of Law and Economics, 26 (3): 613-633.

Wibowo, A., and Rossieta, H. 2009. Faktor-faktor determinasi kualitas audit suatu studi dengan pendekatan earning surprise benchmark. Working Paper, Pascasarjana Ilmu Akuntansi Universitas Indonesia. 